\title{
PENGARUH KEPEMILIKAN INSTITUSIONAL, KEPEMILIKAN MANAJERIAL DAN KONSENTRASI KEPEMILIKAN TERHADAP PERSISTENSI LABA
}

\author{
DUDI PRATOMO \\ ATHIYYA NADHIFA NURAULIA \\ Telkom University, Jl. Telekomunikasi, Terusan Buah Batu, Bandung, Indonesia \\ dudipratomo@telkomuniversity.ac.id,athiyyann@gmail.com
}

\begin{abstract}
Earnings Persistence is a revision of earnings to see company sustainable profits, this become an important aspect in earnings information for decision making.Population in this study used property, real estate and construction companies listed on the Indonesia Stock Exchange in 2013-2017. The total sample of the study were 17 companies. Data analysis using multiple linear regression and the process used software eviews 10 . Results this study indicate that together institutional ownership, managerial ownership and ownership concentration as well as the level of debt and company size affect earnings persistence with a coefficient of determination of $30.18 \%$. Partial test shows that institutional ownership, managerial ownership, ownership concentration and company size negatively affect earnings persistence while the level of debt does not affect earnings persistence.
\end{abstract}

Keywords: Institusional ownership, managerial ownership, consentration of ownership, leverage, company size, earnings persistence

Abstrak: Persistensi Laba merupakan revisi laba untuk melihat laba perusahaan yang berkesinambungan, ini menjadi aspek penting dalam informasi laba untuk pengambilan keputusan. Populasi penelitian menggunakan perusahaan property, real estate dan konstruksi yang terdaftar di bursa efek Indonesia periode 2013-2017. Total sampel penelitian adalah sebanyak 17 perusahaan. Analisis data dengan regresi linear berganda dan prosesnya melalui software eviews 10. Hasil dari penelitian ini menunjukkan bahwa secara simultan kepemilikan institusional, kepemilikan manajerial dan konsentrasi kepemilikan serta tingkat hutang dan ukuran perusahaan memiliki pengaruh terhadap persistensi laba dengan koefisien determinasi sebesar $30,18 \%$. Uji parsial menunjukkan kepemilikan institusional, kepemilikan manajerial , konsentrasi kepemilikan dan ukuran perusahaan berpengaruh negative terhadap persistensi laba, kemudian tingkat hutang tidak memiliki pengaruh terhadap persistensi laba.

Kata kunci: Kepemilikan institusional, kepemilikan manajerial, konsentrasi kepemilikan, tingkat hutang, ukuran perusahaan, persistensi laba

\section{PENDAHULUAN}

Laporan keuangan berfungsi sebagai penyedia informasi yang menyangkut mengenai keseluruhan kinerja perusahaan yang akan digunakan sebagai alat pengambil keputusan. Laba merupakan salah satu komponen yang digunakan guna menilai kinerja perusahaan, karena laba dapat mencerminkan kondisi dari suatu perusahaan dengan cara memprediksi informasi dan segala rasio keuangan di dalam laporan keuangan (IAI 2018). Laba sebagai angka yang tertera dalam laporan keuangan yang merupakan salah satu aspek pemicu 
konflik keagenan, mendapatkan laba yang berkualitas akan meminimalkan terjadinya masalah dalam hubungan keagenan perusahaan (Salsabiila 2016). Kemampuan laba untuk prediksi laba masa yang akan datang dapat dianggap sebagai laba yang berkualitas. Persistensi laba dianggap sebagai alat ukur guna mengetahui apakah laba yang dihasilkan berkualitas dan memiliki kesinambungan. Laba dikatakan persisten apabila laba tidak berfluktuatif serta dapat mencerminkan keberlanjutan laba dimasa yang akan datang atau jangka panjang. Persistensi laba menjadi poin penting karena didalamnya terkandung informasi berguna bagi investor mengenai kinerja perusahaan yang dicerminkan dalam laba di masa depan (Penman and Zhang 1999)

Persistensi laba menjadi hal yang penting karena semakin persisten suatu laba perusahaan maka investor akan semakin mampu untuk memprediksi laba di masa yang akan datang. Jika suatu perusahaan memiliki laba yang persisten maka akan ada anggapan perusahaan tersebut diminati oleh investor karena memiliki prediksi laba yang akan membuat keuntungan perusahaan jelas atau setidaknya bisa diantisipasi. Sektor industri Real Estate, Properti dan Konstruksi bisa mengalami perkembangan yang baik namun juga bisa mengalami penurunan yang signifikan (Aliiya 2014).Salah satu perusahaan dari lima pengembang terbesar dalam sektor ini yakni Ciputra Development (CTRA ) mengalami perkembangan yang baik dari tahun ketahun. Perusahaan ini tidak berfluktuasi dan telah mencerminkan laba yang persisten. Ciputra Development (CTRA) selama periode 20132017 tetap memiliki laba bersih stabil dalam kisaran 1 Triliun dan mengalami fluktuatif yang sangat kecil, kemudian kenaikan dan penurunan labanya sejalan dengan kenaikan dan penurunan penjualan dalam perusahaan yang menunjukkan bahwa perusahaan CTRA memiliki pengendalian yang baik dalam kinerja perusahaannya untuk menunjukkan kepersistenan labanya.

Penelitian ini merupakan pengembangan dari penelitian Arisandi dan Astika (2019), Dewata, Sari dan Fithri (2016), Junawatiningsih dan Harto (2014). Tujuan Penelitian ini adalah untuk mendapatkan bukti bahwa menghasilkan laba yang persisten dapat dipengaruhi oleh beberapa faktor, diantaranya kepemilikan institusional, kepemilikan manajerial, konsentrasi kepemilikan, tingkat hutang dan ukuran perusahaan. Berdasarkan penelitian terdahulu masih ditemukan inkonsistensi terkait faktor-faktor yang memengaruhi persistensi laba, yaitu kepemilikan institusional, kepemilikan manajerial, konsentrasi kepemilikan, tingkat hutang dan ukuran perusahaan. Oleh karena itu, masih dianggap relevan melakukan penelitian mengenai faktor-faktor yang memengaruhi persistensi laba pada perusahaan sektor properti, real estate dan konstruksi di BEI pada 2013 hingga 2017.

\section{Teori Keagenan}

Menurut Jensen dan Meckling (1976) teori agensi atau teori keagenan melukiskan sebuah hubungan yang terjadi dikarenakan kontrak perjanjian yang telah ditetapkan antara principal yang mana merupakan pemegang saham yang menggunakan jasa agen yang dalam perusahaan adalah manajemen untuk mewujudkan berbagai kepentingannya. Manajemen sendiri dianggap pihak yang dikontrak atau pekerjakan para pemegang saham untuk melakukan pekerjaan sesuai kepentingan pemegang saham, ini berarti agen atau manajemen akan melakukan segala tindakan atau pekerjaannya berdasarkan perjanjian yang telah disetujui dengan principal. Maka diantara manajer dengan pemegang saham harus ada keselarasan tujuan dalam memaksimalkan kinerja, jika tidak terjadi keselarasan tujuan maka akan menyebabkan 
terjadinya masalah keagenan. (Jensen and Meckling 1976)

Teori agensi melukiskan bahwa struktur kepemilikan memiliki hubungan yang dapat mengurangi konflik keagenan, karena kepemilikan manajerial akan melihat banyaknya seorang manajer yang mempunyai saham diperusahaan yang termotivasi untuk memaksimalkan pekerjaanya guna meningkatkan laba yang dihasilkan perusahaan. Begitu pula kepemilikan institusional yang akan mengawasi kinerja manajernya (Tandelilin and Wilberforce 2015). Dengan meningkatnya laba maka akan terdapat kepuasan yang dirasa oleh pemegang saham juga manajemen sehingga terjadi keselarasan tujuan.

\section{Persistensi Laba}

Persistensi laba sebagai revisi dalam laba tahun berjalan. Persistensi merupakan laba yang memiliki kemampuan menggambarkan laba period mendatang yang dihasilkan perusahaan secara berkesinambungan dan dengan jangka waktu yang panjang. Laba yang persisten cenderung tidak berfluktuatif disetiap periode berjalannya, laba yang berfluktatif (tidak persisten) dapat menurunkan daya prediksi laba dalam memperkirakan aliran kas perusahaan di masa depan. Penurunan yang terjadi dalam daya prediksi laba dapat berdampak pada kurang bermanfaatnya informasi laba tahun berjalan guna memprediksi laba masa depan (Nadya and Zultilisna 2018)

\section{Kepemilikan Institusional dan Persistensi Laba}

Dalam kepemilikan institusional investor luar perusahaan dianggap mampu mengendalikan manajemen perusahaan. Investor institusi biasanya sudah memiliki pengetahuan dan sumber daya yang cukup serta lebih luas dibandingkan dengan investor individu. Investor institusi juga dapat mempengaruhi perusahaan dengan mengendalikan tekanan akan isu dan aktifitas tertentu saat proses pengambilan keputusan internal melalui manajemen. Oleh sebab itu, investor institusi sebagai pihak yang dapat memonitor agen dengan kepemilikan yang cenderung besar, sehingga manajer lebih termotivasi dan keinginan untuk menata laba menjadi berkurang atau meningkatkan kinerja manajer untuk menghasilkan laba daripada melakukan manipulasi laba. Maka dapat disimpulkan semakin besar jumlah kepemilikan institusional akan semakin meningkatkan persistensi laba perusahaan. (Dewata, Sari and Fithri 2016)

\section{$\mathrm{H}_{1}$ : Kepemilikan institusional berpengaruh terhadap persistensi laba}

\section{Kepemilikan Manajerial dan Persistensi Laba}

Kepemilikan manajerial dapat mengukur serta menilai kualitas laba mendatang yang dicerminkan dari persistensi laba, semakin banyak saham yang diperoleh oleh manajemen maka menimbulkan lebih besar rasa tanggung jawab manajer untuk mempertanggungjawabkan laporan keuangan melalui kinerjanya. (Arisandi and Astika 2019) $\mathrm{H}_{2}$ : Kepemilikan manajerial berpengaruh terhadap persistensi laba

\section{Konsentrasi Kepemilikan dan Persistensi Laba}

Konsentrasi kepemilikan dianggap menjadi aspek yang sangat mempengaruhi kontrol di perusahaan, hal ini menyangkut dengan konsentrasi kepemilikan dibagi menjadi dua yaitu kepemilikan mayoritas dan minoritas. Pemegang saham mayoritas akan mengendalikan perusahaan agar bisa mengawasi manajemen perusahaan dalam berperilaku curang melaporkan informasi keuangan perusahaannya. Informasi yang dilaporkan haruslah relevan dan handal karena informasi keuangan seringkali digunakan oleh para investor terbesar perusahaan dalam menentukan ataupun membuat keputusan akuntansi (Junawatiningsih and Harto 2014). 
Penggunaan laba untuk menentukan serta membuat keputusan akuntansi diharapkan dapat memberikan nilai prediksi yang tinggi mengenai nilai laba dimasa mendatang atau untuk melihat kepersistenan suatu perusahaan. Sehingga pengendalian serta pengawasan oleh pemegang saham mayoritas akan meningkatkan persistensi laba yang berkesinambungan dimasa mendatang.

$\mathrm{H}_{3}$ : Konsentrasi kepemilikan berpengaruh terhadap persistensi laba

Di bawah ini terdapat gambar kerangka pemikiran dalam penelitian ini:

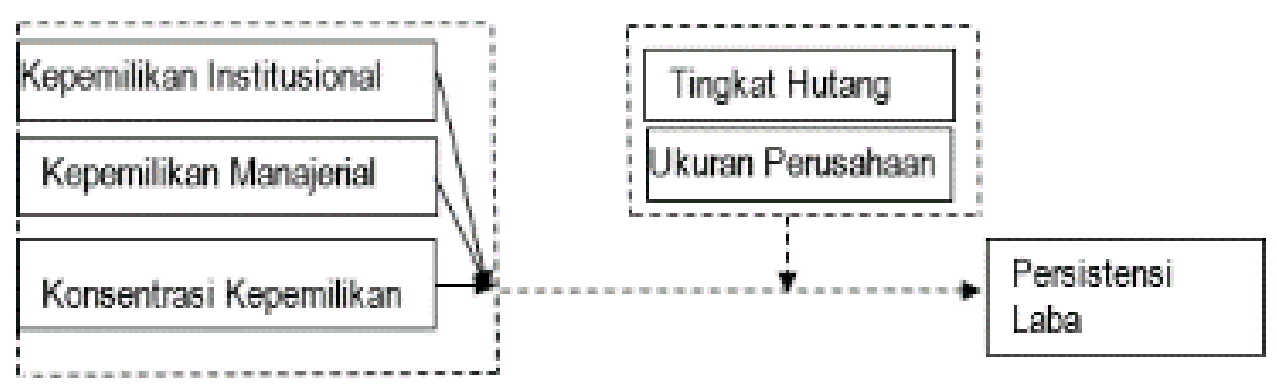

$\longrightarrow$ Berpengaruh secara parsial

$\ldots \rightarrow$ Berpengaruh secara simultan

Gambar 1 Kerangka Pemikiran (Sumber: Data Penelitian, 2020)

\section{METODE PENELITIAN}

Penelitian ini menggunakan metode kuantitatif. Populas penelitian ini menggunakan perusahaan sektor Properti, Real Estatel dan Konstruksi yang terdaftar di BEI peiode 20132017. Metode pemilihan sampel yang digunakan adalah purposive sampling, dengan kriteria perusahaan sebagai berikut:

1. Perusahaab Sektor Properti, Real Estate dan Konstruksi yang konsisten terdaftar di Bursa Efek Indonesia pada tahun 2013-2017.

2. Perusahaan Sektor Properti, Real Estate dan Konstruksi yang menerbitkan laporan keuangan di Bursa Efek Indonesia pada tahun 2013-2017.

3. Perusahaan Sektor Properti, Real Estate dan Konstruksi yang tidak mengalami kerugian selama tahun 2013-2017.

4. Perusahaan Sektor Properti, Real Estate dan Konstruksi yang memiliki kelengkapan informasi yang dibutuhkan terkait dengan indikator- indikator perhitungan yang dijadikan variabel pada penelitian ini.

Variabel - variabel dalam penelitian ini antara lain:

1. Variabel $Y$ penelitian ini adalah Persistensi Laba.

2. Variabel $X$ penelitian ini adalah Kepemilikan Institusional, Kepemilikan Manajerial, Konsentrasi kepemilikan.

3. Variabel Kontrol dalam penelitian ini adalah Tingkat Hutang dan Ukuran Perusahaan

Operasional variabel dalam penelitian ini antara lain:

1. Persistensi Laba

Persistensi merupakan laba yang mempunyai kemampuan sebagai indikator laba periode mendatang yang dapat dihasilkan perusahaan secara 
berulang-ulang dengan jangka waktu panjang, atau sering dianggap sebagai revisi dalam laba tahun berjalan. Laba yang persisten cenderung tidak berfluktuatif disetiap periode berjalannya, laba yang berfluktatif (tidak persisten) dapat menyebabkan menurunnya daya prediksi laba untuk memprediksi aliran kas perusahaan dimasa yang akan datang. Penurunan yang terjadi dalam daya prediksi laba dapat mengakibatkan infromasi laba periode tahun berjalan menjadi kurang bermanfaat dalam memprediksi laba masa depan (Jumiati and Ratnadi 2014). Persistensi laba yang diukur dengan koefisien regresi sebelum pajak tahun berjalan terhadap laba sebelum pajak tahun depan. (Scott 2009) menggolongkan laba menjadi laba persisten dan tidak persisten, Laba yang dianggap persisten laba yang memiliki nilai persisten lebih dari 0 . Maka persamaan yang digunakan sebagai berikut.

Persistensi Laba $=$ PTBlt $-1=a+\beta$ PTBlt $+e$

2. Kepemilikan Institusional

Kepemilikan institusional dapat didefinisikan sebagai sejumlah proporsi saham yang dimiliki oleh institusi baik swasta domestic maupun asing (Dewata, Sari and Fithri 2016). Kepemilikan institusional menjadi aspek yang amat besar dalam meminimalisir konflik keagenan seperti yang dijelakan teori agensi diiatas. Semakin besar kepemilikan institusi semakin besar pula kekuatan institusi dan lembaga terkait untuk mengawasi pihak manajemen perusahaan dalam segala aktivitasnya. Keberadaan investor institusional dianggap memumpuni monitoring perusahaan untuk mendapatkan keefektifan tiap-tiap keputusan yang diambil oleh manajer atau manajemen. Maka hal tersebut akan mengakibatkan dorongan untuk mengoptimalkan kinerja keuangan termasuk persistensi laba. Kepemilikan institusional diukur dengan rumus berikut:

$$
\mathrm{KI}=\frac{\text { Jumlah Saham Institusional }}{\text { Total Saham yang Beredar }} \times 100 \%
$$

\section{Kepemilikan Manajerial}

Kepemilikan manajerial didefinisikan sebagai sejumlah saham yang dimiliki oleh pihak manajemen maupun direktur perusahaan. Kondisi ini menyebabkan pihak manajemen memiliki jabatan ganda yaitu sebagai manajemen perusahaan serta pemegang saham yang berperan aktif dalam segala pengambilan keputusan yang dilaksanakan (Nurochman and Solikhah 2015).Kepemilikan manajerial diukur melalui rumus berikut:

$$
\mathrm{KM}=\frac{\text { Jumlah Saham Manajemen }}{\text { Total Saham yang beredar }} \times 100 \%
$$

4. Konsentrasi Kepemilikan

Konsentrasi kepemilikan menjelaskan bagaimana kendali keseluruhan atau sebagian dan menggambarkan siapa saja yang memegang kendali atas kepemilikan dan pemegang kendali atas seluruh aktivitas perusahaan. Investor yang memiliki saham lebih besar atau mayoritas akan mempunyai wewenang atau kendali lebih tinggi (Junawatiningsih and Harto 2014).Dapat disimpulkan pula bahwa kosentrasi kepemilikan merupakan sekelompok pengendali atas aktivitas bisnis perusahaan yang memiliki ha katas kepemilikan suatu perusahaan sebesar dengan investasi yang mereka berikan. 


$$
\mathrm{KK}=\frac{\text { Jumlahsaham terbesar individu } / \text { kelompok }}{\begin{array}{c}
\text { Total Saham yang beredar } \\
\times 100 \%
\end{array}}
$$

5. Tingkat Hutang

Leverage atau Tingkat hutang menggambarkan seberapa tinggi aktivitas perusahaan didanai dengan utang. Perusahaan yang memiliki tingkat hutang tinggi menunjukkan arti bahwa perusahaan tersebut bergantung pada pinjaman dari eksternal untuk membiayai asset dan jalannya perusahaan. Sedangkan jika tingkat hutang rendah berarti perusahaan tersebut leih banyak mendanai sendiri asset perusahaannya (Kasmir 2017). Pengukuran leverage dapat dihitung dengan cara membandingkan utang dan aktiva perusahaan.

$$
\text { DAR }=\frac{\text { Total Utang }}{\text { Total Aset }} \times 100 \%
$$

6. Ukuran Perusahaan

Ukuran Perusahaan atau size menunjukkan mengenai besar atau kecil suatu perusahaan yang ditunjukkan oleh total keseluruhan aktiva, dan penjualan. Perusahaan dengan ukuran lebih besar akan lebih menarik perhatian pemegang saham, perusahaan akan menganggap bahwa pengungkapan resiko sebagai cara untuk meningkatkan reputasi perusahaannya (Arisandi and Astika 2019)

$$
\text { Size }=L n \times \text { Total Aset }
$$

Analisis data penelitian ini dilakukan dengan teknik analisis regresi linear berganda serta menggunakan eviews 10 , kemudian melakukan uji asumsi klasik sebagai cara memastikan model regresi di penelitian ini telah bebas dari masalah uji uji.

Bentuk model regresi linear berganda ditunjukkan oleh persamaan dibawah ini:

$$
\begin{gathered}
P R S T=\alpha+\beta 1 \text { KIit }+\beta 2 \text { KMit }+ \\
\beta 3 \text { KKit }+\beta 4 \text { Lit }+\beta 5 \text { Sit }+e
\end{gathered}
$$

\section{Keterangan:}

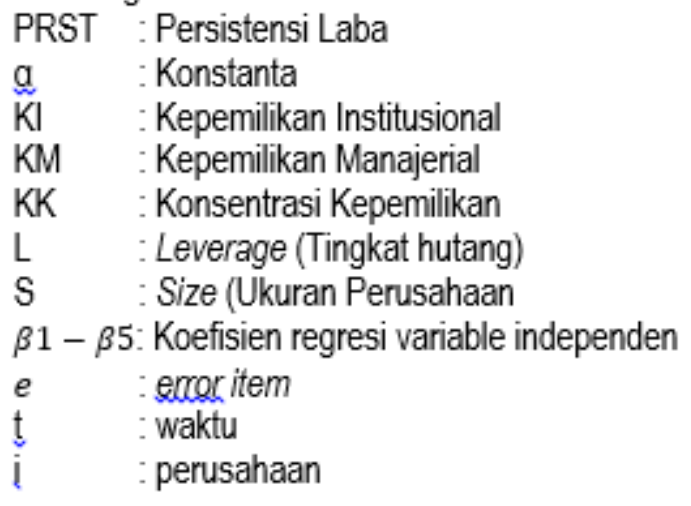

\section{HASIL PENELITIAN}

Hasil statistik deskriptif dan hipotesis dapat dilihat pada tabel-tabel dibawah ini: 
Tabel 1 Statistik Deskriptif

\begin{tabular}{cccccc}
\hline Variabel & N & Minimum & Maksimum & Mean & Std. Deviation \\
\hline KI & 76 & 0,08659 & 0,99467 & 0,64472 & 0,23507 \\
KM & 76 & 0,00000 & 0,06818 & 0,01658 & 0,02031 \\
KK & 76 & 0,14343 & 0,82410 & 0,49707 & 0,17909 \\
TH & 76 & 0,07881 & 0,77286 & 0,47841 & 0,17321 \\
UP & 76 & 26,62761 & 32,21492 & 29,49327 & 1,22553 \\
PL & 76 & $-1,83924$ & 1,74755 & 0,36141 & 0,73182 \\
\hline
\end{tabular}

Sumber: Data Penelitian, 2020

Tabel 2 Hasil Uji Hipotesis

\begin{tabular}{cccc}
\hline Variabel & Koefisien & $\mathbf{t}$ & Signifikansi \\
\hline Konstanta & 7,7096 & 2,9715 & 0,0041 \\
KI & $-0,9226$ & $-2,4914$ & 0,0151 \\
KM & $-11,0642$ & $-2,4023$ & 0,0189 \\
KK & $-1,6458$ & $-4,0206$ & 0,0001 \\
TH & 0,5637 & 0,9687 & 0,3360 \\
UP & $-0,2041$ & $-2,2646$ & 0,0266 \\
\hline
\end{tabular}

Sumber: Data Penelitian, 2020

Persistensi laba di perusahaan sektor properti, real estate dan konstruksi yang terdaftar di BEI periode 2013-2017 menunjukkan bahwa memiliki nilai minimum 1,83924 dan nilai makimum 1,74755 . Nilai mean dari persistensi laba sebesar 0,36141 dengan nilai standar deviasi 0,73182 . Hal ini menunjukkan bahwa variabel persistensi laba memiliki data yang bervariasi.

Kepemilikan institusional dalam penelitian ini menunjukkan bahwa memiliki nilai minimum 0,08659 dan nilai maximum 0,99467 . Nilai mean dari kepemilikan institusional 0,64472 dengan nilai standar deviasi 0,23507 . Hal ini menunjukkan bahwa variabel kepemilikan institusional memiliki data yang tidak bervariasi.

Kepemilikan manajerial dalam penelitian ini menunjukkan bahwa memiliki nilai minimum 0,0000 dan nilai maximum 0,06818 . Nilai mean dari kepemilikan manajerial 0,01658 dengan nilai standar deviasi 0,02031 . Hal ini menunjukkan bahwa variabel kepemilikan manajerial memiliki data yang bervariasi.
Konsentrasi kepemilikan dalam penelitian ini menunjukkan bahwa memiliki nilai minimum 0,14343 dan nilai maximum 0,82410 . Nilai mean dari konsentrasi kepemilikan 0,49707 dengan nilai standar deviasi 0,17909 . Hal ini menunjukkan bahwa variabel konsentrasi kepemilikan memiliki data yang tidak bervariasi.

Tingkat hutang dalam penelitian ini menunjukkan bahwa memiliki nilai minimum 0,07881 dan nilai maximum 0,77286 . Nilai mean dari tingkat hutang sebesar 0,47841 dengan nilai standar deviasi 0,17321 . Hal ini menunjukkan bahwa variabel tingkat hutang memiliki data yang tidak bervariasi.

Ukuran perusahaan dalam penelitian ini menunjukkan bahwa memiliki nilai minimum 26,62761 dan nilai maximum 32,219492 . Nilai mean dari ukuran perusahaan sebesar 29,49327 dengan nilai standar deviasi 1,22553. Hal ini menunjukkan bahwa variabel ukuran perusahaan memiliki data yang tidak bervariasi.

Kepemilikan Institusional memiliki nilai probabilitas sebesar 0,0151 dimana nilai ini lebih kecil atau dibawah dari taraf signifikansi yaitu 0,05 dengan nilai koefisien 0,922 kearah negatif. Hal 
ini diartikan bahwa kepemilikan institusional berpengaruh negatif signifikan terhadap persistensi laba.

Matriks kepemilikan institusional menunjukkan dari 76 sampel variabel kepemilikan institusional yang memiliki nilai diatas mean sebanyak 47 sampel, sedangkan yang memiliki nilai dibawah mean sebanyak 29 . Dari data tersebut dapat dilihat bahwa nilai kepemilikan institusional pada perusahaan yang tergolong tidak persisten sebanyak 24 sampel dan sebanyak 52 sampel tergolong persisten namun 26 sampel perusahaan yang sudah persisten memiliki nilai kepemilikan institusional dibawah rata-rata.

Hal tersebut mengindikasikan kepemilikan institusional memiliki monitoring yang rendah terhadap perusahaan dan juga kepemilikan institusional dimiliki oleh banyak institusi, institusi yang berbeda memiliki kepentingan yang berbeda-beda juga yang akan menyebabkan manajemen perusahaan kesulitan memenuhi keinginan berbagai institusi sehingga kinerja perusahaan tidak optimal. Hal ini yang menyebabkan kepemilikan institusional mempengaruhi secara negatif terhadap persistensi laba. Hasil dalam penelitian ini sejalan seperti penelitian yang dilakukan oleh Dewata, Sari dan Fithri (2016) dimana kepemilikan institusional berpengaruh negatif terhadap persistensi laba.

Kepemilikan Manajerial memiliki nilai probabilitas sebesar 0,0189 dimana nilai ini lebih kecil atau dibawah dari taraf signifikansi yaitu 0,05 dengan nilai koefisien sebesar 11,064 kearah negatif. Hal ini menyatakan kepemilikan manajerial berpengaruh negatif signifikan terhadap persistensi laba. Nilai rata-rata kepemilikan manajerial lebih mendekati nilai minimum yaitu sebesar 0,01658 yang berarti rata-rata kepemilikan manajerial pada sampel ini cenderung rendah.

Matriks kepemilikan manajerial menunjukkan dari 76 sampel variabel kepemilikan manajerial yang memiliki nilai diatas mean sebanyak 31 sampel, sedangkan yang memiliki nilai dibawah mean sebanyak 45 . Dari data tersebut dapat dilihat bahwa nilai kepemilikan manajerial pada perusahaan yang tergolong tidak persisten sebanyak 24 sampel dan sebanyak 52 sampel tergolong persisten namun 37 sampel perusahaan yang sudah persisten memiliki nilai kepemilikan manajerial dibawah rata-rata.

Hal ini memperlihatkan bahwa kepemilikan manajerial memiliki proporsi kecil sehingga memiliki monitoring serta kontribusi yang rendah terhadap perusahaan. Dengan kecilnya kepemilikan saham yang dimiliki manajer menyebabkan kurangnya motivasi bagi manajemen untuk meningkatkan kinerja sehingga mempengaruhi secara negatif terhadap persistensi laba.

Konsentrasi Kepemilikan memiliki nilai probabilitas sebesar 0,0001 dimana nilai ini lebih kecil atau dibawah dari taraf signifikansi yaitu 0,05 dengan nilai koefisien sebesar 1,645 kearah negatif. Hal ini berarti konsentrasi kepemilikan yang dinilai oleh kepemilikan mayoritas berpengaruh negatif signifikan terhadap persistensi laba.

Matriks konsentrasi kepemilikan menunjukkan dari 76 sampel variabel konsentrasi kepemilikan yang memiliki nilai diatas mean sebanyak 38 sampel, sedangkan yang memiliki nilai dibawah mean sebanyak 38 . Dari data tersebut dapat dilihat bahwa nilai konsentrasi kepemilikan pada perusahaan yang tergolong tidak persisten sebanyak 24 sampel dan sebanyak 52 sampel tergolong persisten namun 28 sampel perusahaan yang sudah persisten memiliki nilai konsentrasi kepemilikan dibawah rata-rata.

Hal tersebut mengindikasikan konsentrasi kepemilikan memiliki monitoring yang rendah. dan pemilik saham mayoritas dianggap kurang bisa mengendalikan manajemen untuk menghasilkan informasi yang relevan dan handal sehingga kinerja perusahaan juga tidak maksimal. Maka hal ini 
yang menyebabkan kepemilikan mayoritas mempengaruhi secara negatif terhadap persistensi laba.

Nilai profitabilitas (F-Statistic) memiliki nilai sebesar 0,000011 lebih kecil atau dibawah nilai signifikansi 0,05 . Maka dapat disimpulkan bahwa kepemilikan institusional, kepemilikan manajerial dan konsentrasi kepemilikan serta tingkat hutang dan ukuran perusahaan secara simultan memiliki pengaruh signifikan terhadap persistensi laba.

Nilai adjusted $R$-square 0,301873 atau $30,18 \%$, maka dapat disimpulkan kepemilikan institusional, kepemilikan manajerial dan konsentrasi kepemilikan serta tingkat hutang dan ukuran perusahaan dapat menggambarkan variansi dari persistensi laba sebesar 30,18\% dan sisanya $69,82 \%$ digambarkan oleh faktor lainnya diluar variabel terkait dalam penelitian ini.

\section{PENUTUP}

Sesuai dengan hasil penelitian maka disimpulkan beberapa hal sebagai berikut:

1. Berdasarkan pengujian hipotesis secara simultan menunjukkan bahwa kepemilikan institusional, kepemilikan manajerial dan konsentrasi kepemilikan secara bersamaan berpengaruh terhadap persistensi laba pada perusahaan sektor properti, real estate dan konstruksi yang terdaftar di BEI periode 2013-2017 dengan koefisien determinasi sebesar $30,18 \%$

2. Berdasarkan pengujian secara parsial menunjukkan bahwa:

a. Kepemilikan Institusional berpengaruh negatif terhadap persistensi laba pada perusahaan properti, real estate dan konstruksi di BEl periode 2013-2017.

b. Kepemilikan manajerial berpengaruh negatif terhadap persistensi laba pada perusahaan properti, real estate dan konstruksi di BEl periode 2013-2017. c. Konsentrasi kepemilikan berpengaruh negatif terhadap persistensi laba pada perusahaan properti, real estate dan konstruksi di BEI periode 2013-2017.

Penelitian ini menyadari masih terdapat beberapa kekurangan dan kesalahan, hal tersebut membuat penelitian ini juga memiliki keterbatasan, antara lain:

1. Sampel penelitian adalah perusahaan properti, real estate dan konstruksi yang mana kurang dari 100 perusahaan.

2. Penelitian ini menggunakan 3 variabel independen, sedangkan terdapat variabel independen lainnya yang diduga dapat mempengaruhi persistensi laba.

3. Penelitian ini menggunakan laba sebelum pajak dan total asset untuk mengukur persistensi laba, sedangkan masih banyak metode pengukuran lainnya.

Dalam mengatasi keterbatasan penelitian ini, penulis memberikan beberapa rekomendasi terhadap penelitian kedepannya antara lain:

1. Menambah atau mengganti objek penelitian dengan sektor lain seperti sektor manufaktur dan sektor-sektor jasa lainnya yang terdaftar di BEI (Bursa Efek Indonesia) ataupun perusahaan terdaftar di Indeks Kompas100, Indeks LQ45, Jakarta Islamic Index (JII) sehingga memberikan gambaran lebih jelas mengenai kepemilikan institusional, kepemilikan manajerial dan konsentrasi kepemilikan serta pengaruhnya terhadap persistensi laba yang terjadi di perusahaan lain.

2. Dapat menggunakan variabel keuangan seperti book tax differences atau keandalan akrual dan variabel nonkeuangan lainnya yang dapat berpengaruh terhadap persistensi laba 
ke dalam penelitian lainnya. Kemudian untuk variabel yang telah terkandung dalam penelitian ini agar lebih dicermati.
3. Penelitian selanjutnya bisa menggunakan metode pengukuran persistensi laba lainnya.

\section{REFERENCES:}

Aliiya. 2014. IHSG Tumbuh Tertinggi di Dunia Saham properti paling tinggi. Juni 2. Accessed Oktober 14, 2019. http://finance.detik.com/bursa-valas/2597322/ihsg-tumbuh-tertinggi-di-dunia-saham-properti-palingkinclong.

Arisandi, Ni N, and Ida B Astika. 2019. "Pengaruh tingkat hutang, ukuran perusahaan dan kepemilikan manajerial pada persistensi laba." e-jurnal universitas udayana 26 (3).

Basuki, A T, and N Prawoto. 2016. Analisis regresi dalam penelitian ekonomi dan bisnis: dilengkapi dengan aplikasi spss dan eviews. Jakarta: Raja Grafindo Persada.

Dewata, E, Y Sari, and E J Fithri. 2016. "Kepemilikan manajerial dan kepemilikan institusional sebagai determinan struktur modal dan persistensi laba." jurnal riset dan aplikasi: akuntansi dan manajemen (JRAAM) 1 (3).

Ghozali, I. 2016. Aplikasi analisis multivariate. Semarang: Badan penerbit universitas diponegoro.

IAl. 2018. Standar Akuntansi Keuangan. Jakarta: Salemba.

Jensen, M C, and W H Meckling. 1976. "Theory of firm: Managerial behavior, agency cost and ownership structure." Journal of Financial Economic 3 (4) 305-360.

Jumiati, $F$, and N D Ratnadi. 2014. "Pengaruh kepemilikan manajerial dan book tax differences pada persistensi laba." e-jurnal akuntansi universitas udayana 8.2 91-101.

Junawatiningsih, T, and P Harto. 2014. "Analisis pengaruh mekanisme internal dan eskternal corporat governance terhadap persistensi laba." Diponegoro journal accounting.

Kasmir. 2017. Analisis laporan keuangan. Jakarta: Raja Grafindo Persada.

Nadya, Namira F, and D Zultilisna. 2018. "Analisis faktor-faktor penentu persistensi laba." Jurnal Akrab Juara 3 (3) 157-169.

Nurochman, A, and B Solikhah. 2015. "Pengaruh good corporate governance, tingkat hutang dan ukuran perusahaan terhadap persistensi laba." accounting analysis journal 4 (4).

Penman, S H, and X J Zhang. 1999. "Accounting Conservatisme The quality of earnings and stocks returns." Accounting Conservatisme.

Salsabiila, Azzahra. 2016. "Pengaruh book tax differences dan aliran kas operasi terhadap persistensi laba." jurnal akuntansi 314-329.

Scott, W R. 2009. Financial accounting Theory. fifth edition. Canada: Prentice hall.

Tandelilin, E, and Wilberforce. 2015. Portofolio dan Investasi teori dan aplikasi. Yogyakarta: Kanisius. 